\title{
Peran Notaris Dalam Penggunaan Akta SKMHT Yang Tidak Diikuti APHT Terhadap Debitor Wanprestasi Terkait Pemberian Fasilitas Kredit Pemilikan Rumah Subsidi (Studi Kasus di Bank Tabungan Negara Pekalongan)
}

\author{
Rifki Yusuf*, Maryanto**

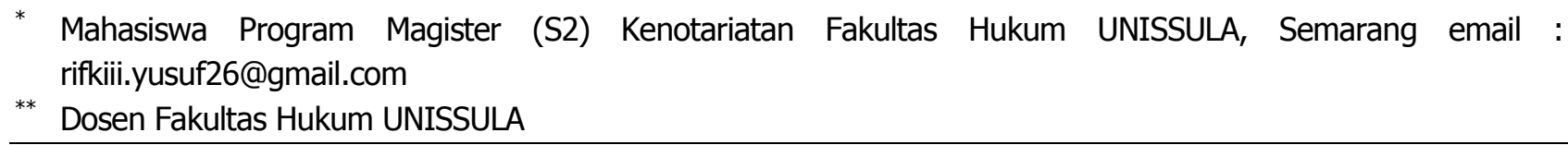

\begin{abstract}
ABSTRAK
Kabupaten Pekalongan merupakan lokasi yang memiliki potensi tinggi dalam penggunaan Surat Kuasa Membebankan Hak Tanggungan (SKMHT), hal ini disebabkan oleh gencarnya pembangunan oleh masyarakat yang membutuhkan dana besar yang antara lain berasal dari kredit yang diperoleh dengan menggunakan lembaga Hak Tanggungan yang selanjutnya menimbulkan berbagai masalah seperti apabila debitor wanprestasi. BTN selaku kreditor dalam pemberian KPR bersubsidi kepada debitor umumnya tidak menguasai benda yang menjadi jaminan kredit secara fisik, tetapi hanya memiliki hak kebendaan secara administratif. Pengikatan obyek jaminan yang berupa tanah, yaitu Hak Milik, Hak Guna Bangunan dan Hak Guna Usaha, prosesnya hanya sampai dengan Surat Kuasa Membebankan Hak Tanggungan (SKMHT) saja, dengan tidak dibebankan Hak Tanggungan atas obyek jaminan tersebut, maka BTN belum memiliki hak kebendaan atas jaminan tersebut secara faktual.

Tujuan dari penelitian ini adalah untuk mengkaji dan menganalisis peran notaris dalam hal debitor wanprestasi, penggunaan SKMHT yang tidak diikuti APHT dalam hal debitor wanprestasi terkait dengan pemberian fasilitas Kredit Pemilikan Rumah Subsidi pada Bank Tabungan Negara serta upaya pihak Bank Tabungan Negara dalam hal debitor wanprestasi terhadap pemberian fasilitas Kredit Pemilikan Rumah. Metode yang digunakan dalam penelitian ini adalah metode analisis kualitatif, yaitu data yang diperoleh disusun secara sistematis kemudian dianalisis secara kualitatif agar dapat diperoleh kejelasan masalah yang akan dibahas.

Dalam penelitian ini disimpulkan bahwa dalam menghadapi debitor wanprestasi Bank BTN mengambil langkah melakukan penjualan kembali dengan menggunakan kuasa menjual yang tercantum dalam akta "Pengakuan Hutang", serta peningkatan SKMHT ke APHTkepada calon debitor, dan peran notaris yang hanya sebagai pembuat akta sehingga tidak turut serta jika terjadi wanprestasi.
\end{abstract}

Kata kunci: Notaris, SKMHT, APHT, wanprestasi

\begin{abstract}
Pekalongan Regency is a location that has a high potential in the use of Power of Attorney Charging the Guarantee Right (SKMHT), this is caused by incessant development by people who need big fund which among others comes from the credit obtained by using the Mortgage Institution which further cause various problems such as if the debtor is defaulted. BTN as a creditor in the granting of subsidized KPR to the debtor generally does not control objects that become credit for physical security, but only have the right of property administratively. The binding of the object of collateral in the form of land, namely Right of Ownership, Building Rights and Cultivation Right, the process is only up to the Power of Attorney Charging the Guarantee Right (SKMHT) only, without the burden of the Guaranteed Fund on the object of the guarantee, BTN has no material right the guarantee is factual.

The purpose of this study is to examine and analyze the role of a notary in the case of debtor wanprestasi, the use of SKMHT not followed APHT in the case of debtor wanprestasi associated with the provision of Subsidized House Ownership Credit in the State Savings Bank and the efforts of the State Savings Bank in the case of debt defaulting to the grant Housing Loan facility. The method used in this study is the method of qualitative analysis, the data obtained is arranged systematically and then analyzed qualitatively in order to obtain clarity of issues to be discussed.

In this study it is concluded that in the face of debtor wanprestasi Bank BTN take steps to resell by using the power of sale which stated in deed "Recognition of Debt", and increase SKMHT to APHT to debitor candidate, and notary role which only as deed maker so do not participate if there was a default.
\end{abstract}

Keywords: notary, SKMHT, APHT, wanprestasi

\section{PENDAHULUAN}

Kebutuhan akan perumahan sekarang ini sudah sangat mendesak untuk dapat dilakukan pembenahan, dimana lahan yang tersedia semakin sempit dan sangat sulit didapat sedangkan 
kebutuhan akan perumahan sangat meningkat. Perbankan adalah salah satu solusi bagi masyarakat yang membutuhkan dana untuk dapat membeli rumah, salah satu perbankan yang memberikan fasilitas Kredit Pemilikan Rumah yang ada di Indonesia diantaranya adalah Bank Tabungan Negara (BTN), dimana BTN adalah salah satu bank Badan Usaha Milik Negara (BUMN) yang bisnis utamanya adalah pembiayaan perumahan dan salah satu bank yang pemerintah tunjuk dalam hal pembiayaan Kredit Pemilikan Rumah bersubsidi, hal ini bertujuan memberikan pelayanan bagi masyarakat yang kurang mampu dalam membeli rumah.

Sumber dana perbankan yang disalurkan kepada masyarakat dalam bentuk kredit harus dilakukan dengan prinsip kehati-hatian melalui analisa yang akurat dan mendalam. Prinsip tersebut bertujuan supaya kredit yang disalurkan dapat kembali tepat pada waktunya sesuai perjanjian kredit yang telah dibuat dan disetujui.

Dana yang diperoleh bank tersebut bersumber dari masyarakat, oleh karena itu dalam memberikan kredit bank wajib mempunyai keyakinan terhadap debitor dimana sesuai Undang-undang Nomor 10 tahun 1998 tentang Perubahan atas Undang-undang Nomor 7 tahun 1992 tentang perbankan ditentukan :

1. Kredit yang diberikan oleh bank mengandung resiko.

2. Untuk mengurangi resiko tersebut, bank harus mempunyai keyakinan atas kemampuan dan kesanggupan dari debitor untuk melunasi utangnya.

3. Untuk memperoleh keyakinan tersebut, sebelum memberikan kredit, bank melakukan penilaian yang seksama terhadap :
a. Watak;
b. Kemampuan;
c. Modal;
d. Agunan/jaminan;
e. Prospek usaha;

Obyek yang menjadi jaminan kredit bank itu haruslah disesuaikan dengan pedoman yang digunakan oleh bank yang bersangkutan, antara lain mengenai jaminan yang diperbolehkan untuk suatu pemberian kredit, sehingga jaminan tersebut benarbenar dapat menjadi alat pelunasan kredit yang efektif apabila terjadi wansprestasi yang dilakukan debitor, maka sudah menjadi keharusan jika pemberi dan penerima kredit serta pihak lain yang terkait mendapat perlindungan melalui lembaga hak jaminan yang kuat dan dapat memberikan kepastian hukum bagi semua pihak yang berkepentingan.

Interaksi hal tersebut dapat secara nyata dilihat dari lahirnya Undang-Undang Nomor 4 Tahun 1996 tentang Hak Tanggungan Atas Tanah Beserta BendabendaYang Berkaitan Dengan Tanah (selanjutnya disebut UUHT). Dalam butir a menimbang bahwa Undang-Undang tersebut menyatakan:bahwa dengan bertambahnya Pembangunan Nasional yang bertitik berat pada bidang ekonomi, dibutuhkan penyediaan dana yang cukup besar, sehingga memerlukan lembaga hak jaminan yang kuat dan mampu memberi kepastian hukum bagi pihak-pihak yang berkepentingan, yang dapat mendorong peningkatan partisipasi masyarakat dalam pembangungan untuk mewujudkan masyarakat yang sejahtera, adil dan makmur berdasarkan Pancasila dan Undang-Undang Dasar 1945.

Di Indonesia, lahirnya lembaga jaminan atas tanah yaitu Hak Tanggungan diamanatkan dalam Pasal 51 Undang-Undang Nomor 5 Tahun 1960 tentang Peraturan Dasar Pokok-Pokok Agraria (selanjutnya disebut UUPA). Dalam waktu 36 tahun akhirnya lahirlah undang-undang yang dimaksud.

Kelahiran Undang-Undang Nomor 4 Tahun 1996 dimaksudkan untuk menggantikan ketentuan mengenai Credietverband dan Hipotik atas tanah, hal ini merupakan perubahan yang mendasar dalam Hukum Jaminan, khususnya hukum jaminan kebendaan, mengenai tanah dan hal ini ditegaskan pula dalam Pasal 29 UUHT NO. 4 Tahun 1996 bahwa :Dengan berlakunya Undang-undang (tersebut)ini, ketentuan mengenai Credietverband sebagaimana tersebut dalam Staatsblad 1908-452 jo Staatsblad 1909-686 dan Staatsblad 1909-584 sebagai yang telah diubah dengan Staatsblad 1937-190 jo. Staatsblad 1937-191 dan ketentuan mengenai Hypoteek sebagaimana tersebut dalam buku II Kitab Undang-Undang Hukum Perdata Indonesia sepanjang mengenai pembebanan Hak Tanggungan pada hak atas tanah beserta benda-benda yang berkaitan dengan tanah dinyatakan tidak berlaku lagi. UUHT ini bertujuan memberikan landasan untuk dapat berlakunya lembaga Hak Tanggungan yang kuat, diantaranya mengenai kedudukan Surat Kuasa Membebankan Hak Tanggungan (SKMHT).

Pasal 15 Ayat (3) Undang-Undang Hak Tanggungan menyatakan bahwa untuk hak atas tanah yang sudah terdaftar, Surat Kuasa Membebankan Hak Tanggungan (SKMHT) wajib diikuti dengan Akta Pemberian Hak Tanggungan selambat-lambatnya 1 (satu) bulan setelah Surat Kuasa Membebankan Hak Tanggungan (SKMHT) ditandatangani. Pasal 15 Ayat (4) Undang-Undang Hak Tanggungan menyatakan bahwa untuk hak atas tanah yang belum terdaftar wajib diikuti dengan Akta Pemberian Hak Tanggungan selambat-lambatnya 3 (tiga) bulan setelah Surat kuasa Membebankan Hak Tanggungan (SKMHT) ditandatangani. Batas waktu 
tiga bulan itu berlaku juga bilamana hak atas tanah yang bersangkutan sudah bersertifikat tetapi belum tercatat atas nama pemberi Hak Tanggungan sebagaipemegang haknya yang baru. ${ }^{1}$

Penjelasan Pasal 15 ayat (5) UUHT menentukan bahwa ketentuan Pasal 15 ayat (3) dan (4) tersebut tidak berlaku bagi Surat kuasa Membebankan Hak Tanggungan (SKMHT) untuk jenis kredit tertentu, yaitu KUK, KUT, KPR. Menurut Pasal 1 Peraturan Menteri Negara Agraria Nomor 4 tahun 1996 tentang Penetapan Batas Waktu penggunaan Surat Kuasa Membebankan Hak Tanggungan (SKMHT) untuk menjamin pelunasan kredit-kredit tertentu, jangka waktu berlakunya Surat Kuasa Membebankan Hak Tanggungan (SKMHT) sampai saat berakhirnya perjanjian pokok yang bersangkutan.

Kredit Pemilikan Rumah yang diberikan untuk pengadaan perumahan menurut Pasal 1 ayat (2) Peraturan Menteri Negara Agraria/Kepala BPN Nomor 4 Tahun 1996 tentang Penetapan Batas Waktu Penggunaan Surat Kuasa Membebankan Hak Tanggungan untuk menjamin jenis-jenis Kredittertentu yaitu :

a. Kredit yang diberikan untuk membiayai pemilikan rumah inti, Rumah Sederhana atau Rumah Susun dengan luas tanah maksimum 200 M2 (duaratus meter persegi) dan luas bangunan tidak lebih dari 70 M2 (tujuhpuluh meter persegi).

b. Kredit yang diberikan untuk pemilikan Kapling Siap Bangun (KSB) dengan luas tanah 54 M2 (lima puluh empat meter persegi) sampai dengan 72 M2 (tujuh puluhdua meter persegi) dan kredit yang diberikan untuk membiayai bangunannya.

c. Kredit yang diberikan untuk perbaikan/ pemugaran rumah sebagaimana dimaksud huruf $a$ dan $b$.

BTN selaku kreditor dalam pemberian Kredit Pemilikan Rumah bersubsidi kepada debitor umumnya tidak menguasai benda yang menjadi jaminan kredit secara fisik, tetapi hanya memiliki hak kebendaan secara administratif. Pengikatan obyek jaminan yang berupa tanah, yaitu Hak Milik, Hak Guna Bangunan dan Hak Guna Usaha, prosesnya hanya sampai dengan Surat Kuasa Membebankan Hak Tanggungan (SKMHT) saja, dengan tidak dibebankan Hak Tanggungan atas obyek jaminan tersebut, maka BTN belum memiliki hak kebendaan atas jaminan tersebut secara faktual.

Kabupaten Pekalongan merupakan lokasi yang

${ }^{1}$ Boedi Harsono, Hukum Agraria Indonesia: Sejarah Pembentukan Undang-Undang Pokok Agraria, Isi dan Pelaksanaanya, cet 8, (Jakarta: Djambatan 2007), hlm. 443. memiliki potensi tinggi dalam penggunaan Surat Kuasa Membebankan Hak Tanggungan (SKMHT), hal ini disebabkan oleh gencarnya pembangunan oleh masyarakat yang membutuhkan dana besar yang antara lain berasal dari kredit yang diperoleh dengan menggunakan lembaga Hak Tanggungan yang selanjutnya menimbulkan berbagai masalah seperti apabila debitor wanprestasi. Hal tersebut yang menjadikan penulis tertarik melakukan penelitian mengenai Surat Kuasa Membebankan Hak Tanggungan (SKMHT) yang akan penulis susun dalam penelitian yang berjudul : "Peran Notaris Dalam Penggunaan Akta SKMHT yang tidak diikuti APHT terhadap debitor wanprestasi terkait pemberian fasilitas kredit pemilikan rumah di Bank Tabungan Negara Pekalongan."

Berdasarkan latar belakang diatas, maka penulis mengambil rumusan masalah yaitu bagaimana penggunaan Surat Kuasa Membebankan Hak Tanggungan (SKMHT) yang tidak diikuti APHT dalam hal debitor wanprestasi terkait dengan pemberian fasilitas Kredit Pemilikan Rumah pada Bank Tabungan Negara serta bagaimana upaya pihak Bank Tabungan Negara dan peran notaris dalam hal debitor wanprestasi terhadap pemberian fasilitas Kredit Pemilikan Rumah. Secara umum tujuan dari penelitian ini adalah untuk mengkaji dan menganalisis penggunaan SKMHT yang tidak diikuti APHT dalam hal debitor wanprestasi terkait dengan pemberian fasilitas Kredit Pemilikan Rumah pada Bank Tabungan Negara serta upaya pihak Bank Tabungan Negara dan peran notaris dalam hal debitor wanprestasi terhadap pemberian fasilitas Kredit Pemilikan Rumah

\section{Metode Penelitian}

Berdasarkan rumusan masalah dan tujuan penelitian, maka Metode yang digunakan dalam penelitian ini adalah metode analisis kualitatif, yaitu data yang diperoleh disusun secara sistematis kemudian dianalisis secara kualitatif agar dapat diperoleh kejelasan masalah yang akan dibahas.

\section{HASIL DAN PEMBAHASAN}

Penggunaan SKMHT Yang Tidak Diikuti APHT Dalam Hal Debitor Wanprestasi Terkait dengan Pemberian Fasilitas Kredit Pemilikan Rumah pada Bank Tabungan Negara.

Pemberian kredit pada umumnya dilakukan oleh pihak bank (kreditur) karena pendapatan dan keuntungan suatu bank lebih banyak bersumber dari pemberian kredit kepada debitur (nasabah). Hal ini sesuai dengan ketentuan Pasal 3 Undang-Undang 
Nomor 7 Tahun 1992 tentang Perbankan, bahwa fungsi utama perbankan Indonesia adalah sebagai penghimpun dana dan penyalur dana masyarakat. Hal ini mempunyai pengertian bahwa apabila seseorang atau suatu badan usaha mendapatkan fasilitas kredit dari bank maka orang atau badan usaha tersebut mendapatkan kepercayaan dari bank pemberi kredit. Dari sudut pandang ekonomi, kredit diartikan sebagai penundaan pembayaran artinya pembayaran pengembalian atas penerimaan uang dan atau suatu barang tidak dilakukan bersamaan pada saat menerimanya, tetapi pengembaliannya pada masa tertentu yang akan datang.

Perjanjian kredit bank ialah perjanjian pendahuluan dari penyerahan uang. Perjanjian pendahuluan ini merupakan hasil permufakatan antara pemberi dan penerima pinjaman mengenai hubungan-hubungan antara keduanya. Penyerahan uang bersifat riil, pada saat penyerahan uang dilakukan barulah berlaku ketentuan yang dituangkan dalam perjanjian kredit pada kedua belah pihak. Ketentuan yang berlaku dalam perjanjian kredit adalah ketentuan yang ditetapkan sendiri oleh para pihak dan ketentuan umum dalam Buku III KUHPerdata. ${ }^{2}$

Pada ketentuan Pasal 8 Undang-Undang Nomor 10 Tahun 1998 perubahan atas Undang-Undang Nomor 7 Tahun 1992 tentang Perbankan menjelaskan bahwa: "Dalam memberikan kredit bank wajib mempunyai keyakinan terhadap debitur". Selanjutnya dalam penjelasan Pasal 8 tersebut ditegaskan bahwa untuk memperoleh keyakinan tersebut maka pihak bank sebelum memberikan kredit harus melakukan penilaian yang seksama terhadap calon debitur, antara lain: ${ }^{3}$

1. Character (watak)

2. Capacity (kemampuan)

3. Capital (modal)

4. Collateral (agunan)

5. Condition of economy (prospek perusahaan dari nasabah)

Dari ketentuan penilaian diatas yang umumnya digunakan pada dunia perbankan menjadi tolak ukur dalam menganalisa calon debitur oleh pihak bank sebagai pemberi kredit.

Perjanjian kredit oleh bank kepada debitur selalu dimulai dengan permohonan oleh pihak debitur. Apabila bank menganggap permohonan tersebut layak, untuk diberikan maka akan terlaksana pelepasan kredit tersebut berdasarkan perjanjian. Dalam praktek perbankan bentuk dan format dari

\footnotetext{
2Mariam Darus Badrulzaman, Aneka Hukum Bisnis, Cet.I, Bandung : Alumni, 1994), hal. 147.

${ }^{3}$ Ibid
}

perjanjian kredit diserahkan sepenuhnya kepada bank yang bersangkutan. Sebagaimana yang dijelaskan sebelumnya, bahwa perjanjian kredit merupakan perjanjian pendahuluan dari penyerahan uang. Perjanjian tersebut bersifat konsensuil obligatoir, karena untuk terlaksananya dibutuhkan kata sepakat antara pemberi dan penerima kredit mengenai hubungan hukum antara keduanya yang menimbulkan hak dan kewajiban.

Suatu perjanjian kredit mempunyai fungsi yang sangat penting dalam pemberian, pengelolaan maupun pelaksanaan kredit. Dimana fungsi dari perjanjian kredit tersebut yakni sebagai berikut:

a. Sebagai perjanjian pokok artinya perjanjian kredit merupakan sesuatu yang menentukan ada tidaknya perjanjian lain yang mengikutinya, misalnya pengikatan jaminan.

b. Sebagai bukti mengenai batasan-batasan hak dan kewajiban diantara kreditur dan debitur.

c. Sebagai alat untuk melakukan monitoring kredit.

Selanjutnya bank berhak menghentikan pemberian kredit dengan segera atau pada waktu yang ditentukan oleh bank. Dalam keadaan ini maka seluruh utang dapat ditagih dengan seketika atau pada waktu yang ditentukan. Perjanjian dapat dihentikan oleh bank apabila dalam pelaksanaan perjanjian tersebut:

a. Si berhutang menurut bank telah melakukan perbuatan yang bertentangan dengan syaratsyarat persetujuan atau pengakuan hutang atau syarat-syarat perjanjian tersebut.

b. Menurut bank, barang yang ditanggungkan sudah tidak cukup lagi dan tanggungan ini tidak ditambah baik karena musnah atau hilang ataupun harganya mundur.

c. Jika nasabah bank adalah suatu perusahaan maka jika perusahaan tersebut sudah dihentikan atau menurut bank tidak akan memberikan pelunasan atau karena sebab-sebab lain sehingga tidak diusahakan lagi oleh yang berhutang sendiri.

Dalam praktiknya suatu kredit dibagi atas beberapa golongan, diantaranya: ${ }^{4}$

1) Kredit dilihat dari tujuannya terdiri dari:

a) Kredit Konsumtif yaitu kredit yang diberikan dengan tujuan untuk memperoleh atau membeli barang-barang dan kebutuhankebutuhan konsumsi, keperluan memenuhi tuntutan kebutuhan hidup.

b) Kredit Produktif yaitu kredit yang diberikan dengan tujuan untuk memperlancar jalannya proses produksi.

\footnotetext{
4 Hassanudin Rahman, Aspek-Aspek Hukum Pemberian Kredit Perbankan di Indonesia, PT. Citra Aditya Bakti, Bandung, 1995.
} 
2) Kredit dilihat dari sudut jangka waktu terdiri dari:

a) Kredit jangka pendek yaitu kredit yang berjangka waktu maksimum 1 (satu) tahun.

b) Kredit jangka menengah yaitu kredit yang berjangka waktu 1 (satu) s/d 3 (tiga) tahun.

c) Kredit jangka panjang yaitu kredit yang berjangka waktu lebih dari 3 (tiga) tahun.

3) Kredit dilihat dari jaminannya yaitu:

a) Kredit tanpa jaminan yaitu atau yang seiring disebut dengan istilah blangko, diberikan kepada nasabah tanpa adanya jaminan, Pemberian kredit ini tidak berarti tidak ada jaminan sama sekali, melainkan jaminan yang berbentuk bonafiditas dan prospek usaha debitur tetap diperhatikan dan ditekankan dengan sungguh-sunguh dalam pertimbangan kreditnya.

b) Kredit dengan jaminan yaitu pemberian kredit dengan jaminan dari debitur, yang berupa harta benda atau surat berharga atau jaminan perorangan.

Berdasarkan penggolongan tersebut di atas, Kredit Pemilikan Rumah (KPR) termasuk dalam kredit konsumtif, karena kredit diberikan kepada debitur yang lazimnya dipergunakan untuk membeli rumah sebagai tempat tinggal atau dihuni yang merupakan salah satu dari kebutuhan pokok manusia. Dalam perjanjian Kredit Pemilikan Rumah (KPR) ada 3 (tiga) pihak yang terkait yaitu: ${ }^{5}$

a) Pihak debitur yaitu pihak pembeli rumah yang dibangun oleh developer dengan uang yang dipinjam dari bank.

b) Pihak kreditur yaitu pihak bank sebagai bank penyandang dana yang menberikan bantuan fasilitas kredit dalam bentuk uang yang dipergunakan oleh debitur untuk membayar rumah yang dibeli dari developer.

c) Developer yaitu pengembang dan pembangun proyek-proyek perumahan yaitu rumah-rumah yang dijual kepada pembeli baik secara tunai maupun kredit.

Untuk menjamin pembayaran kredit sesuai dengan ketentuan perjanjian kredit, debitur menyetujui memberikan rumah dan tanah yang dibeli dengan kredit bank tersebut.

Perjanjian pemberian kuasa mempunyai pengertian sebagaimana dijelaskan pada Pasal 1792 KUHPerdata: "suatu perjanjian dengan mana seorang memberikan kekuasaan kepada orang lain, yang menerimanya, untuk atas namanya menyelenggarakan suatu urusan". Dimaksud dengan menyelenggarakan suatu urusan yaitu melakukan suatu

\footnotetext{
${ }^{5}$ Ibid
}

perbuatan hukum, yakni tindakan subjek hukum yangdapat menimbulkan suatu akibat hukum yang dikehendaki oleh pelaku. Dalam perjanjian pemberian kuasa terdapat 2 pihak didalamnya, yaitu:

a) Pihak yang memberi kuasa yang biasa disebut pemberi kuasa.

b) Pihak yang menerima kuasa yang biasa disebut penerima kuasa.

Adapun unsur-unsur yang dapat membedakan antara pemberian kuasa dengan zaakwarneming adalah bahwa untuk mewakili urusan orang lain diharuskan seseorang itu berbuat dengan sukarela (kesediaan menolong tanpa imbalan) tanpa mendapat perintah untuk itu, sedangkan pemberian kuasa sebaliknya, yaitu disyaratkan adanya suatu perintah. Si juru kuasa melakukan perbuatan hukum tersebut atas nama atau mewakili pemeri kuasa, artinya bahwa apa yang dilakukan oleh sikuasa adalah atas tanggungan si pemberi kuasa dan segala hakdan kewajiban yang timbul dari perbuatan yang dilakukan si kuasa menjadi hak dan kewajiban orang yang memberi kuasa. ${ }^{6}$

Pada penggunaan Surat Kuasa Membebankan Hak Tanggungan ini, untuk mencegah berlarutlarutnya pelaksanaan dari Surat Kuasa membebankan Hak Tanggungan (SKMHT) dan agar dapat segera dilakukan secara nyata, maka SKMHT dibatasi jangka waktu berlakunya untuk hak atas tanah yang belum didaftar yaitu berlaku 3 (tiga) bulan. Apabila tidak terpenuhinya jangka waktu tersebut maka dapat berakibat batal demi hukum.

Sebelum pelaksanaan akad perjanjian Kredit Pemilikan Rumah (KPR) adapun syarat-syarat pengajuan kredit tersebut telah dipenuhi oleh pemohon sebagai debitur, yang diantaranya:

a. Memenuhi pembayaran uang muka yang telah ditentukan oleh pihak bank sebagai pemberi fasilitas Kredit Pemilikan Rumah (KPR);

b. Memenuhi persyaratan administrasi

c. Terhadap telah memenuhi syarat-syarat uang muka maupun admistrasi maka akan disetujui oleh pihak bank

d. Unit rumah haruslah telah selesai dikerjakan oleh pengembang.

Selanjutnya dalam tahapan pengikatan perjanjian, dilakukan dengan perjanjian kredit yang dengan melakukan: ${ }^{7}$

${ }^{6}$ R. Subekti, Aneka Perjanjian, Cetakan Ke VII,Alumni, Bandung,1985, hal. 113.

${ }^{7}$ Wawancara Dengan Legal Officer PT. Bank BTN Cabang Pekalongan, Pada Tanggal 26 Februari 2018. 
a. Perjanjian kredit antara Bank Tabungan Negara (BTN) Cabang Pekalongan dengan nasabah yang dilegalisir oleh notaris.

b. Dibuatkannya Akta Pengakuan Hutang antara debitur dengan Bank BTN Cabang Pekalongan selaku kreditur.

c. Dibuatkan Akta Jual Beli antara debitur dengan pengembang.

d. Dibuatkannya SKMHT antara debitur dengan Bank BTN cabang Pekalongan, yang selanjutnya untuk dipasangkan dan didaftarkan pada kantor pertanahan.

Pada ketentuan Undang-Undang Nomor 4 Tahun 1996 tentang Hak Tanggungan juga mengenal Surat Kuasa Membebankan Hak Tanggungan (SKMHT).Dalam prakteknya Surat Kuasa Membebankan Hak Tanggungan (SKMHT) dibuat sebelum adanya Akta Pemberian Hak Tanggungan (APHT). Selanjutnya Undang-Undang Hak Tanggungan, menghendaki pembuatan SKMHT wajib diikuti dengan pembuatan pemberian Hak Tanggungan. ${ }^{8}$ Dengan demikian agar sahnya suatu Surat Kuasa Membebankan Hak Tanggungan (SKMHT), maka harus dibuat dengan akta otentik oleh Notaris atau Akta Pejabat Pembuat Akta Tanah (PPAT), hal ini dimaksudkan akta notaris sebagai akta otentik yang memiliki kekuatan pembuktian yang kuat. Dimana SKMHT bertujuan untuk menjamin pelunasan suatu kredit tertentu, yang dalam ketentuan Pasal 15 Ayat (1) Undang-Undang Hak Tanggungan menjelaskan beberapa hal yang harus dipenuhi pada SKMHT antara lain: ${ }^{9}$

a. Tidak memuat kuasa untuk melakukan perbuatan hukum lain daripada membebankan Hak Tanggungan.

b. Tidak memuat kuasa substitusi.

c. Mencantumkan secara jelas Objek Hak Tanggungan, jumlahutang dan nama serta identitas krediturnya, nama dan indentitas debitur apabila debitur bukan pemberi HakTanggungan.

Sehingga dapat dipahami bahwa Surat Kuasa Membebankan Hak Tanggungan (SKMHT) tidaklah boleh memuat kuasa untuk menjual maupun menyewakan obyek Hak Tanggungan, atau memperpanjang hak atas tanah, melainkan hanya sebagai sarana pemberian kuasa untuk membuat Akta Pemberian Hak Tanggungan (APHT). Hal ini untuk mencegah berlarut-larutnya waktu pelaksanaan kuasamembebankan hak tanggungan

${ }^{8}$ Gatot Supramono, Perbankan dan Masalah Kredit : Suatu Tinjauan di Bidang Yuridis, PT. Rineka Cipta, Jakarta, 2009, hal 215.

9 Mariam Darus Badrulzaman, Kompilasi Hukum Jaminan, Mandar Maju, Bandung,2004, hlm. 76-77. dan agar segera dilakukan secara nyata,maka Surat Kuasa Membebankan Hak Tanggungan dibatasi jangka waktunya yaitu 3 (tiga) bulan untuk hak atas tanah yang belum terdaftar,yang wajib diikuti dengan pembuatan Akta Pemberian Hak Tanggungan (APHT).Tidak dipenuhinya persyaratan jangka waktu mengakibatkan suratkuasanya batal demi hukum.

Selanjutnya Pasal 15 ayat (1) huruf a Undang Undang Hak Tanggungan disebutkan secara spesifik bahwa salah satu syarat Surat Kuasa Membebankan Hak Tanggungan (SKMHT) adalah tidak memuat kuasa untuk melakukan perbuatan hukum lain daripada membebankan Hak Tanggungan. Oleh karenanya ketentuan Pasal 1796 ayat (2) KUHPerdata menjelaskan: "Untuk memindah tangankan benda-benda atau untuk meletakkan hipotik diatasnya, atau lagi untuk membuat suatu perdamaian, ataupun sesuatu perbuatan lain yang hanya dapat dilakukan oleh seorang pemilik, diperlukan dengan kata-kata yang tegas". Dengan demikian dapat dikatakan bahwa kuasa dalam SKMHT tergolong kuasa yang bersifat khusus.

Mengenai batas waktu penggunaan Surat Kuasa Membebankan Hak Tanggungan (SKMHT) dijelaskan dalam Pasal 15 Ayat(3) dan (4) Undang-Undang Hak Tanggungan. Pasal 15 Ayat(3); "Surat Kuasa Membebankan Hak Tanggungan mengenai hak atas tanah yangsudah didaftar, wajib diikuti dengan pembuatan Akta Pemberian Hak Tanggungan dalam jangka waktu selambat-lambatnya satu bulan sesudah diberikan. Pasal 15 ayat (4); "Surat Kuasa Membebankan Hak Tanggunganmengenai hak atas yangbelum didaftar, wajib diikuti denganpembuatan Akta Pemberian Hak Tanggungan dalam jangka waktu selambat-lambatnya tiga bulan sesudah diberikan". Demikian pula bila mencermati Pasal 15 ayat (5) Undang-Undang Hak Tanggungan yang seolah menegaskan bahwa Surat Kuasa Membebankan Hak Tanggungan (SKMHT) dapat memberikan jaminan terhadap pelunasan sebuah perjanjian kredit tertentu: "Ketentuan sebagaimana dimaksud pada ayat (3) dan ayat (4) tidak berlaku dalam hal Surat Kuasa Membebankan Hak Tanggungan diberikan untuk menjamin kredit tertentu yang ditetapkan dalam peraturan perundang-undangan yang berlaku".

Terkait dengan penelitian yang dilakukan oleh penulis, dalam hal penggunaan SKMHT pada pemberian Kredit Pemilikan Rumah (KPR) oleh Bank Tabungan Negara sebagai pemberi fasilitas, penulis melakukan wawancara dengan pihak Bank Tabungan Negara (BTN) Cabang Pekalongan yang diwakili oleh Legal Officer-nya. Dijelaskan bahwa Bank BTN Cabang Pekalongan pada Perjanjian Kredit Pemilikan Rumah (KPR) yang khususnya untuk jenis KPR 
bersubsidi dalam prakteknya hanya dipasang Surat Kuasa Membebankan Hak Tanggungan (SKMHT) saja tanpa perlu diikuti Akta Pemberian Hak Tanggungan (APHT). Sehingga Surat Kuasa Membebankan Hak Tanggungan (SKMHT) untuk jenis KPR bersubsidi jangka waktu berlakunya selama masa kredit itu berlangsung. Artinya SKMHT akan berakhir apabila perjanjian kredit tersebut telah berakhir atau adanya pelunasan oleh debitur atas beban kreditnya. ${ }^{10}$

Hal ini kemudian dipertegas dalam Peraturan Menteri Negara Agraria/Kepala Badan Pertanahan Nasional Nomor 4 Tahun 1996 tentang Penetapan Batas Waktu Penggunaan Surat Kuasa Membebankan Hak Tanggungan (SKMHT) untuk menjamin pelunasan kredit-kredit tertentu, sebagaimana pada Pasal 1 menyebutkan; "Surat Kuasa Membebankan Hak Tanggungan yang diberikan untuk menjamin pelunasan jenis-jenis Kredit Usaha Kecil sebagaimana dimaksud dalam Surat Keputusan Direksi Bank Indonesia No. 26/24/KEP/Dir tanggal 29 Mei 1993 tersebut di bawah ini berlaku sampai saat ini berakhirnya masa berlakunya perjanjian pokok yang bersangkutan", diantaranya: ${ }^{11}$

1. Kredit yang diberikan kepada nasabah usaha kecil, yang meliputi :

a. Kredit kepada Koperasi Unit Desa;

b. Kredit Usaha Tani;

c. Kredit kepada Koperasi Primer untuk Anggotanya.

2. Kredit Pemilikan Rumah yang diberikan untuk pengadaan perumahan, yaitu :

a. Kredit yang diberikan untuk membiayai pemilikan rumah inti, rumah sederhana atau rumah susun dengan luas tanah maksimum $200 \mathrm{~m} 2$ (dua ratus meter persegi) dan luas bangunan tidak lebih dari $70 \mathrm{~m} 2$ (tujuh puluh meter persegi);

b. Kredit yang diberikan untuk pemilikan Kapling Siap Bangun (KSB) dengan luas tanah $54 \mathrm{~m} 2$ (lima puluh empat meter persegi) dan kredit yang diberikan untuk membiayai bangunannya;

c. Kredit yang diberikan untuk perbaikan atau pemugaran rumah sebagaimana dimaksud huruf a dan b;

3. Kredit produktif lain yang diberikan oleh Bank Umum dan Bank Perkreditan Rakyat dengan

\footnotetext{
${ }^{10}$ Wawancara Dengan Legal Officer PT. Bank BTN Cabang Pekalongan, Pada Tanggal 26 Februari 2018.

11 Surat Keputusan Direksi Bank Indonesia No. 26/24/KEP/Dir. Tanggal 29 Mei 1993
}

plafond kredit tidak melebihi Rp.50.000.000,00 (lima puluh juta rupiah), antara lain :

a. Kredit Umum Pedesaan (yang disalurkan oleh Bank Pemerintah);

b. Kredit Pelayanan Usaha (yang disalurkan oleh Bank Pemerintah).

Pemasangan Akta Pembebanan Hak Tanggungan (APHT) atau Surat Kuasa Membebankan Hak Tanggungan (SKMHT), apabila kredit macet atau wanprestasi maka debitur telah memberi kuasa kepada Bank selaku kreditur untuk dilakukan penyitaan atas objek jaminan tersebut. Dalam hal Surat Kuasa Membebankan Hak Tanggungan (SKMHT) untuk tanah yang sudah terdaftar wajib diikuti dengan pembuatan Akta Pembebanan Hak Tanggungan (APHT) selambatlambatnya 1 (satu) bulan setelah diberikan sedangkan untuk hak atas tanah dan bangunan yang belum terdaftar pembuatan APHT dilakukan selambat-lambatnya 3 (tiga) bulan sesudah diberikan. Di sisi lain Surat Kuasa Membebankan Hak Tanggungan (SKMHT) tersebut berakibat batal demi hukum bila tidak diikuti dengan pembuatan Akta Pembebanan Hak Tanggungan (APHT). Akan tetapi untuk jenis Kredit Pemilikan Rumah (KPR) untuk rumah sederhana dan rumah sangat sederhana hanya dipasang Surat Kuasa Membebankan Hak Tanggungan (SKMHT) dengan tidak ada batas waktunya, berlaku selama masa kredit.

Dalam Akta Pemberian Hak Tanggungan (APHT) atau Surat Kuasa Membebankan Hak Tanggungan (SKMHT) harus mencantumkan obyek hak tanggungan, jumlah uang dan nama serta identitas kreditur dan debiturnya kalau tidak mencantumkan batal demi hukum. Debitur menyetujui dan mewajibkan serta mengikat diri untuk menyerahkan semua surat dan dokumen apapun, yang asli serta sah dan membuktikan pemilikan atas segala harta yang dijadikan jaminan kepada Bank guna dipergunakan untuk pelaksanaan pengikatan harta tersebut sebagai jaminan kredit dan selanjutnya dikuasai Bank sampai dilunasi seluruh jumlah utangnya.

Dengan demikian, penggunaan Surat Kuasa Membebankan Hak Tanggungan (SKMHT) dalam pemberian fasilitas Kredit Pemilikan Rumah (KPR) oleh Bank BTN Cabang Kabupaten Pekalongan dalam pelaksanaannya tidak diikuti dengan Akta Pemberian Hak Tanggungan (APHT), sehingga penggunaan SKMHT berlaku jangka waktunya sampai dengan berakhirnya perjanjian pokok, yakni perjanjian kredit tersebut. Dengan mengacu pada Peraturan Menteri Negara Agraria/Kepala Badan Pertanahan Nasional Nomor 4 Tahun 1996 tentang penetapan batas 
waktu penggunaan Surat Kuasa Membebankan Hak Tanggungan (SKMHT) untuk menjamin pelunasan kredit-kredit tertentu, yang dalam hal ini Kredit Pemilikan Rumah (KPR) bersubsidi oleh Bank BTN Cabang Kabupaten Pekalongan sebagai pemberi fasilitas.

\section{Upaya Pihak Bank Tabungan Negara Dalam Hal Debitur Wanprestasi Terhadap Pemberian Fasilitas Kredit Pemilikan Rumah Subsidi}

Mengenai kuasa untuk membebankan ini sebelumnya sudah dikenal dalam lembaga Hipotik melalui Surat Kuasa Membebankan Hipotik. Dengan berlakunya Undang-Undang Hak Tanggungan maka istilah Surat Kuasa Membebankan Hipotik menjadi tidak populer lagi karena pada pemberian kuasa untuk membebankan Hak Tanggungan dilakukan melalui Surat Kuasa Membebankan Hak Tanggungan (SKMHT). Surat Kuasa Membebankan Hipotik adalah pernyataan pemberian kuasa yang diberikan oleh pemberi kuasa atau pemberi Hak Tanggungan dalam bentuk tertulis atau otentik yang dbuat oleh atau di hadapan Notaris atau oleh Pejabat Pembuat Akta Tanah (PPAT) dengan maksud untuk digunakan pada waktu melakukan pemberian Hak Tanggungan dalam hal pemberi Hak Tanggungan tidak dapat hadir sendiri di hadapan pejabat Pembuat Akta Tanah dalam rangka pembuatan Akta Pemberian Hak Tanggungan. ${ }^{12}$

Menurut ketentuan Pasal 1171 ayat (2) KUH Perdata, kuasa untuk memasang hipotik harus dibuat dengan akta otentik. Di dalam pelaksanaannya (praktiknya) akta otentik itu adalah akta Notaris. Tidak demikian halnya untuk Surat Kuasa Membebankan Hak Tanggungan (SKMHT). Pasal 15 ayat (1) Undang-Undang Hak Tangungan menegaskan bahwa Surat Kuasa Membebankan Hak Tanggungan wajib dibuat dengan akta notaris atau akta PPAT dan memenuhi persyaratan sebagai berikut :

a) tidak memuat kuasa untuk melakukan perbuatan hukum lain dari pada membebankan Hak Tanggungan;

b) tidak memuat kuasa substitusi;

c) mencantumkan secara jelas objek Hak Tanggungan, jumlah utang dan nama serta identitas krediturnya, nama dan identitas debitur apabila debitur bukan pemberi Hak Tanggungan Menurut Undang-Undang Nomor 30 Tahun 2004 tentang Jabatan Notaris.

\footnotetext{
${ }^{12}$ Fieda Husni Hasbullah, Hukum Kebendaan Perdata (Hakhak Yang Memberi Jaminan), Jilid 2, IND HILL CO , Jakarta, 2009, hal. 165.
}

Alasan pembuatan Surat Kuasa Membebankan Hipotik harus otentik disamping berdasarkan ketentuan Pasal 1171 KUH Perdata, juga berlatar belakang macam-macam kepentingan dan hambatan terutama karena proses pembebanan atau pemberian atau pemasangan Hipotik tidaklah mudah antara lain disebabkan hal-hal sebagai berikut :

1. Harus melalui suatu formalitas tertentu;

2. Memakan waktu yang lama;

3. Memerlukan biaya pembebanan yang relatif cukup tinggi;

4. Kredit yang diberikan oleh kreditor kepada debitor jangka waktunya pada dasarnya terlalu singkat dan jumlahnya juga tidak terlalu besar;

5. Benda yang akan dijaminkan belum bersertifikat;

6. Kreditor mempercayai debitor artinya ia merasa terjamin bilamana telah mendapat kuasa dari debitor;

7. Pemberi Hipotik kadang-kadang tidak dapat hadir sendiri dihadapan Notaris untuk membuat akta pembebanan Hipotik.

Sebagaimana penjelasan diatas dapat diartikan bahwa dalam suatu pelaksanaan perjanjian kredit terhadap fasilitas kredit pemilikan rumah, juga diperlukan pula Surat Kuasa Membebankan Hak Tanggungan (SKMHT) sebagai perjanjian tambahannya.

Pada dasarnya suatu Hak Tanggungan adalah suatu bentuk jaminan pelunasan utang, dengan hak mendahulu, dengan objek jaminannya berupa hakhak atas tanah yang diatur dalam Undang-Undang Nomor 5 Tahun 1960 tentang Peraturan Dasar Pokok-Pokok Agraria atau UUPA yangmenyatakan bahwa terlaksananya Hak Tanggungan dikenal pemberi (pihak debitur) dan penerima (pihak kreditur) Hak Tanggungan, di mana keduanya mempunyai syarat-syarat yaitu pemberi Hak Tanggungan mempunyai kewenangan atas barangnya, barang yang menjadi objek Hak Tanggungan tersebut tidak boleh dialih fungsikan tanpa persetujuan kreditur sehingga perlu adanya kejelasan jika terjadi pengalih fungsian, sedangkan penerima Hak Tanggungan memerlukan adanya penilaian terhadap barang jaminan berdasarkan lembaga penilaian barang yang bersifat independen dan mampu melakukan penilaian terhadap bonadifitas serta reputasi dari debitur. Selain itu dikenal objek yang digunakan sebagai jaminan harus jelas, mempunyai kepastian tentang dapat atau tidaknya objek hak tanggungan tersebut dibebani Hak Tanggungan, misalnya apabila objek Hak Tanggungan berupa tanah pertanian, kreditur terlebih dahulu harus meminta proses pengeringan dengan maksud apabila terjadi eksekusi, tanah 
tesebut mempunyai nilai lebih. ${ }^{13}$

Hak tanggungan sebagai satu-satunya lembaga hak jaminan atas tanah untuk pelunasan hutang tertentu mempunyai empat asas, yaitu sebagai berikut: ${ }^{14}$

1. Memberikan kedudukan yang diutamakan (preferent) kepada krediturnya. Hal ini berarti bahwa kreditur pemegang Hak Tanggungan mempunyai hak didahulukan di dalam mendapatkan pelunasan atas pihutangnya dari pada kreditur-kreditur lainnya atas hasil penjualan benda yang dibebani Hak Tanggungan tersebut;

2. Selalu mengikuti objeknya dalam tangan siapapun objek tersebut berada, artinya benda-benda yang dijadikan objek Hak Tanggungan itu tetap terbebani Hak Tanggungan walau di tangan siapapun benda itu berada. Jadi meskipun hak atas tanah yang menjadi objek Hak Tanggungan tersebut telah beralih atau berpindah-pindah kepada orang lain, namun Hak Tanggungan yang ada tetap melekat pada objek tersebut dan tetap mempunyai kekuatan mengikat;

3. Memenuhi Asas Spesialitas dan Publisitas. Asas Spesialitas maksudnya wajib dicantumkan berapa yang dijamin serta benda yang dijadikan jaminan, juga identitas dan domisili pemegang dan pemberi Hak Tanggungan yang wajib dicantumkan dalam Akta Pemberian Hak Tanggungan (APHT). Asas Publisitas maksudnya wajib dilakukan dengan akta Pejabat Pembuat Akta Tanah (PPAT) dan wajib didaftarkan pada Kantor Pertanahan; dan

4. Mudah dan pasti pelaksanaan eksekusinya, artinya dapat dieksekusi seperti putusan hakim yang telah berkekuatan hukum tetap dan pasti.

Masalah yang sering timbul dalam pembelian rumah melalui fasilitas Kredit Pemilikan Rumah (KPR) pada umumnya adalah debitur wanprestasi, yang dimana debitur tidak menunaikan kewajibannya sebagai yang telah disepakati pada perjanjian Kredit Pemilikan Rumah (KPR). Yang apabila dalam jangka waktu tertentu debitur tidak dapat membayar angsuran KPR sebagaimana dalam perjanjian kreditnya, maka hal tersebut berpotensi terjadinya kredit macet. Oleh sebab itu, dalam rangka penyelamatan aset bank selaku kreditur berhak

\footnotetext{
${ }^{13}$ Kartini Muljadi dan Gunawan Widjaja, Seri Hukum Harta Kekayaan: Hak Tanggungan, Kencana Prenada Media Group, Jakarta. 2005, hal. 13.

${ }^{14}$ Sutan Remy Sjahdeini, Hak Tanggungan, Asas, KetentuanKetentuan Pokok dan Masalah yang dihadapi oleh Perbankan; Suatu Kajian Mengenai Undang-Undang Hak Tanggungan, Alumni, Bandung, 1999, hal. 383
}

melakukan upaya-upaya sebagaimana dalam perjanjian kredit yang telah disepakati.

Bank Tabungan Negara (BTN) Cabang Pekalongan sebagai bank yang juga memberikan fasilitas Kredit Pemilikan Rumah (KPR) dalam prakteknya bisa saja mengalami suatu hal bilamana debitur wanprestasi, oleh karena itu diperjelas segala ketentuan-ketentuan yang terkait kewajiban debitur maupun dalam hal debitur wanprestasi.

Pada kasus debitur wanprestasi terhadap fasilitas Kredit Pemilikan Rumah (KPR) oleh Bank BTN Cabang Pekalongan, penulis melakukan wawancara dengan Legal Officer Bank BTN Cabang Pekalongan. Dalam pelaksanaannya apabila terjadi wanprestasi oleh debitur, terdapat beberapa upaya penyelamatan aset atau langkah-langkah yang diambil oleh Bank BTN Cabang Pekalongan selaku kreditur terhadap debitur wanprestasi, antara lain sebagai berikut: ${ }^{15}$

a. Menggunakan akta kuasa menjual yang dibuat pada saat realisasi kredit yang pada saat perjanjian kredit ditandatangani.

Bank BTN Cabang Pekalongan dalam menggunakan akta kuasa menjual dibuatkan secara notariil. Artinya dibuatkannya akta kuasa menjual dari pemilik (debitur) kepada bank (kreditur) dengan alasan jika debitur wanprestasi, pihak bank dapat melakukan penjualan aset maupun dengan cara lainnya yang oleh pihak kreditur dianggap perlu dilakukan.

b. Peningkatan SKMHT ke APHT

Pada upaya lainnya selanjutnya dapat dengan meningkatkan SKMHT ke APHT selanjutnya didaftarkan ke kantor pertanahan, yang kemudian pihak bank dapat melakukan eksekusi lelang hak tanggungan setelah diterbitkannya sertifikat hak tanggungan atas aset tersebut. Penjelasan Pasal 15 ayat (1) Undang-Undang Hak Tanggungan yang telah disampaikan sebelumnya tersebut jelas bahwa Surat Kuasa Membebankan Hak Tanggungan (SKMHT) belum memiliki fungsi eksekutorial, sehingga harus dilanjutkan dengan meningkatkan kedudukan Surat Kuasa Membebankan Hak Tanggungan (SKMHT) tersebut menjadi Akta Pemberian Hak Tanggungan (APHT) yang kemudian wajib didaftarkan di kantor Pertanahanatas jaminan yang ada sehingga memiliki fungsi Eksekutorial.

c. Upaya Cessie

Selanjutnya yakni upaya cessie oleh bank selaku kreditur, yaitu dengan cara pengalihan piutang- 
piutang atas nama dan barang-barang lain yang tidak bertubuh dilakukan dengan cara membuat akta otentik atau dibawah tangan, yang melimpahkan hak-hak atas barang atau jaminan kepada orang lain sebagai pihak ketiga atau kreditur baru. Dalam cessie perjanjian accesoirnya tidak dihapus hanya karena beralih kepada pihak ketiga sebagai kreditur baru, begitu pula utang piutang lama tidak dihapus walaupun telah beralih ke kreditur yang baru. Namun sejauh ini upaya cessie sangat jarang digunakan oleh Bank BTN Cabang Pekalongan dalam praktiknya, akan tetapi tidak menutup kemungkinan dipergunakan karena cessie merupakan salah satu dari upaya penyelamatan oleh setiap bank terhadap debitur wanprestasi.

d. Novasi

Upaya novasi merupakan salah satu upaya untuk mengakhiri perjanjian antara bank (kreditur) dan penerima fasilitas kredit (debitur). Novasi juga dapat dimanfaatkan untu melakukan penyelamatan kredit bermasalah dengan cara mengalihkan debitur lama kepada debitur baru berikut aset yang menjadi jaminan kredit yang disebut novasi subyektif pasif atau mengalihkan kreditur lama kepada kreditur baru yang disebut Novasi subyektif aktif atau mengubah isi atau obyek perjanjian sedangkan posisi kreditur dandebitur tidak berubah yang disebut novasi obyektif.

Novasi atau pembaruan utang adalah suatu perjanjian baru yang menghapuskan perjanjian lama dan pada saat yang sama memunculkan perjanjian baru yang menggantikan perjanjian lama. Upaya novasi ini diatur dalam Pasal 1423 jo. Pasal 1424 KUHPerdata. Dimana pada pasal tersebut menguraikan novasi terdiri dari 3 (tiga) jenis, yaitu novasi subyektif pasif, novasi subyektif aktif dan novasi obyektif. Dari tiga jenis novasi tersebut semuanya dapat digunakan untuk melakukan penyelamatan kredit, mengenai jenis mana yang dipilih tergantung kesepakatan kreditur dan debitur berdasarkan analisa dan peluang-peluang yang mungkin dapat dilakukan untuk melakukan penyelamatan kredit. Alih debitur atau novasi subyektif pasif ini dalam prakteknya yang diambil alih oleh debitur baru bukan hanya utangnya tetapi utang dan sebagian atau seluruh jaminannya (aset) tergantung kesepakatan kreditur, debitur lama dan debitur baru. Jaminan ini yang akan dimiliki dan dikelola oleh debitur baru agar menjadi sumber pendapatan yang akan digunakan untuk membayar utangnya kepada kreditur, oleh karenaitu ada dua perbuatan hukum yang harus dilakukan dalam melakukan alih debitur yaitu perbuatan hukum mengalihkan hutang dari debitur lama ke debitur baru dan perbuatan hukum mengalihkan jaminan kredit dari debitur lama kepada debitur baru sebagai kompensasi mengambil alih utang.

Dari hasil wawancara penulis dengan pihak Bank Tabungan Negara (BTN) Cabang Pekalongan diatas, mengenai upaya pihak bank apabila terjadi debitur wanprestasi terhadap fasilitas Kredit Pemilikan Rumah (KPR) oleh Bank Tabungan Negara (BTN) Cabang Pekalongan, dapat disimpulkan bahwa terdapat beberapa upaya atau langkah-langkah yang dapat diambil baik dalam rangka penyelamatan aset kreditur maupun pemanfaatannya. Adapun upaya tersebut yakni dengan menggunakan akta kuasa menjual, peningkatan SKMHT ke APHT, upaya cessie, dan novasi.

\section{Peran Notaris Dalam Hal Debitur Wanprestasi Terhadap Pemberian Fasilitas Kredit Pemilikan Rumah}

Dalam melaksanakan tugas dan wewenang terkait jabatan sebagai notaris yang membuat suatu akta autentik sebagai alat bukti yang sempurna, seorang notaris harus selalu berpedoman serta berpegang teguh pada ketentuan dalam UUJN dan kode etik profesi notaris. Dapat dilihat bahwa dalam melaksanakan tugas dan jabatan notaris, terdapat kewenangan-kewenangan yang melekat pada jabatan notaris antara lain yang terkait dengan :

a. Subjek

Hal ini berkaitan dengan subjek hukum yang berkepentingan terkait akta yang akan dibuat yaitu orang (baik warga negara Indonesia atau warga negara asing) atau badan hukum (badan hukum dalam negeri atau badan hukum asing). Notaris berwenang membuat akta untuk setiap orang namun dengan pembatasan sebagaimana yang diatur dalam Pasal 52 UUJN bahwa: "Tidak diperkenankan membuat akta untuk diri, sendiri, isteri/suami atau orang lain yang mempunyai hubungan kekeluargaan dengan notaris, baik karena perkawinan maupun hubungan darah dalam garis keturunan lurus kebawah dan/atau ke atas tanpa pembatasan derajat, serta dalam garis ke samping sampai dengan derajat ketiga, serta menjadi pihak untuk diri sendiri, maupun dalam suatu kedudukan ataupun dengan perantaraan kuasa." ${ }^{16}$

\footnotetext{
${ }^{16}$ Habib Adjie 2011, Hukum Notaris Indonesia, Tafsir Tematik Terhadap UU Nomor 30 Tahun 2004 Tentang Jabatan Notaris, Refika Aditama, Bandung, hal 77.
} 
b. Objek

Hal ini berkaitan dengan objek dari pembuatan akta yang menurut peraturan perundangundangan jabatan notaris diperbolehkan untuk dibuat oleh seorang notaris dan merupakan kewenangan notaris. Sepanjang tidak dikecualikan kepada pihak atau pejabat lain, atau notaris juga berwenang membuatnya disamping dapat dibuat oleh pihak atau pejabat lain, sebagaimana yang diatur dalam Pasal 15 UUJN.

c. Waktu

Hal ini berkaitan dengan waktu pembuatan akta.

Pembuatan akta yang merupakan produk hukum notaris, harus dilakukan pada saat menjabat sebagai notaris aktif, yang berarti tidak dalam keadaan cuti atau diberhentikan sementara waktu.

d. Tempat

Sebagaimana yang diatur dalam Pasal 18 ayat (1) dan (2) menentukan bahwa tempat kedudukan notaris adalah kabupaten atau kota dan wilayah jabatan notaris meliputi provinsi. Berdasarkan ketentuan tersebut maka notaris memiliki kewenangan untuk membuat produk hukumnya hanya pada wilayah jabatannya. Kewenangan terkait jabatan notaris diberikan berdasarkan peraturan perundang-undangan yang berlaku yang khusus mengatur mengenai jabatan notaris.

Wewenang yang diperoleh suatu jabatan memiliki beberapa sumber yaitu: ${ }^{17}$

1) Atribusi, yaitu pemberian wewenang kepada suatu jabatan berdasarkan suatu peraturan perundang-undangan.

2) Delegasi, merupakan pengalihan atau pemindahan wewenang yang ada berdasarkan peraturan perundang-undangan.

3) Mandat, merupakan pengalihan sementara karena yang bersangkutan berhalangan.

Notaris adalah pejabat umum yang satusatunya berwenang untuk membuat akta otentik mengenai semua perbuatan, perjanjian dan penetapan yang diharuskan oleh suatu peraturan umum atau oleh yang berkepentingan dikehendaki untuk dinyatakan dalam suatu akta otentik, menjamin kepastian tanggalnya, menyimpan aktanya dan memberikan grosse, salinan dan kutipannya, semuanya sepanjang perbuatan akta itu oleh suatu peraturan umum tidak juga ditugaskan atau dikecualikan kepada pejabat atau orang lain. ${ }^{18}$

\footnotetext{
${ }^{17}$ Ibid.

${ }^{18}$ G.H.S. Lumban Tobing, Peraturan Jabatan Notaris, (Jakarta: Erlangga, 1983), hal. 31
}

Notaris dalam menjalankan tugasnya sebagai pejabat umum memiliki kewenangan yang sebagaimana diatur dalam Pasal 15 Undang-Undang Nomor 2 tahun 2014 tentang perubahan atas Undang-Undang Nomor 30 Tahun 2004 tentang Jabatan Notaris, menjelaskan bahwa :

1) Notaris berwenang membuat akta otentik mengenai semua perbuatan, perjanjian, dan penetapan yang diharuskan oleh peraturan perundang-undangan dan/atau yang dikehendaki oleh yang berkepentingan untuk dinyatakan dalam akta otentik, menjamin kepastian tanggal pembuatan akta, menyimpan akta, memberikan grosse, salinan dan kutipan akta, semuanya itu sepanjang pembuatan akta itu tidak juga ditugaskan atau dikecualikan kepada pejabat lain atau orang lain yang ditetapkan oleh undangundang.

2) Selain kewenangan sebagaimana dimaksud pada ayat (1), Notaris berwenang pula:

a) mengesahkan tanda tangan dan menetapkan kepastian tanggal surat di bawah tangan dengan mendaftar dalam buku khusus;

b) membukukan surat di bawah tangan dengan mendaftar dalam buku khusus;

c) membuat kopi dari asli surat di bawah tangan berupa salinan yang memuat uraian sebagaimana ditulis dan digambarkan dalam surat yang bersangkutan;

d) melakukan pengesahan kecocokan fotokopi dengan surat aslinya;

e) memberikan penyuluhan hukum sehubungan dengan pembuatan Akta;

f) membuat akta yang berkaitan dengan pertanahan; atau

g) membuat akta risalah lelang.

Dari penjelasan mengenai kewenangan notaris diatas, pada huruf $\mathrm{F}$ menjelaskan tentang kewenangan notaris dalam membuat akta yang berkaitan dengan pertanahan. Hal ini berarti bahwa notaris memiliki peran dalam setiap lahirnya akta otentik yang berkaitan dengan pertanahan, sehingga setiap penghadap baik individu perorangan maupun badan hukum yang menggunakan jasa notaris atas dibuatkannya akta otentik, maka undang-undang dengan tegas memberikan kepastian hukum serta menjamin akta notaris memiliki kekuatan pembuktian yang kuat atas keotentikannya.

Dalam kaitan peran notaris dalam hal debitur wanprestasi terhadap pemberian fasilitas Kredit Pemilikan Rumah (KPR) oleh Bank Tabungan Negara (BTN) Cabang Pekalongan, notaris dalam hal ini memiliki peranan sejak perjanjian kredit itu dibuat. Dari wawancara penulis dengan salah satu 
Notaris/PPAT menjelaskan, bila melihat dari perjanjian Kredit Pemilikan Rumah (KPR) yang kemudian terjadinya debitur wanprestasi, maka notaris memiliki peransejak awal lahirnya perjanjian kredit, antara lain: ${ }^{19}$

1) Notaris membuat Akta Kuasa Menjual

Oleh pihak Bank Tabungan Negara (BTN)

Cabang Pekalongan kepada Notaris untuk dibuatkan Akta Kuasa Menjual. Akta yang dibuat secara notariil tersebut dibuat dengan tujuan pemberian kuasa untuk menjualobjek jaminan dari pemilik (debitur) kepada bank (kreditur), dengan maksud mengantisipasi jika debitur wanprestasi, pihak bank dapat melakukan penjualan aset maupun dengan cara lainnya yang oleh pihak kreditur dianggap perlu dilakukan.

2) Notaris membuat Surat Kuasa Membebankan Hak Tanggungan (SKMHT)

Ketentuan Pasal 15 Ayat (1) Undang-Undang Hak Tanggungan menentukan bahwa Surat Kuasa Membebankan Hak Tanggungan (SKMHT) wajib dibuat dengan akta Notaris atau akta Pejabat Pembuat Akta Tanah (PPAT). Artinya,sekalipun harus dibuat dengan akta otentik, pilihannya bukan hanya akta Notaris saja tetapi dapat pula dibuat dengan akta Pejabat Pembuat Akta Tanah (PPAT). Dari ketentuan tersebut SKMHT harus memuat mengenai beberapa hal-hal yang diantaranya:

a) Tidak memuat kuasa untuk melakukan perbuatan hukum lain dari pada membebankan Hak Tanggungan.

b) Tidak memuat kuasa substitusi.

c) Mencantumkan secara jelas Objek Hak Tanggungan, jumlahutang dan nama serta identitas krediturnya, nama dan indentitas debitur apabila debitur bukan pemberi Hak Tanggungan.

Oleh karenanya, Surat Kuasa Membebankan Hak Tanggungan (SKMHT) yang dibuatsecara notariil khusus hanya memuat pemberian kuasa untuk membebankan Hak Tanggungan saja.

3) Notaris selaku PPAT membuat Akta Pemberian Hak Tanggungan (APHT)

Pada tahap pembuatan Akta Pemberian Hak Tanggungan (APHT) oleh Notaris/PPAT diminta oleh pihak Bank BTN Cabang Pekalongan bilamana dalam hal debitur wanprestasi terhadap perjanjian fasilitas Kredit Pemilikan Rumah (KPR) oleh Bank Tabungan Negara (BTN)Cabang

\footnotetext{
${ }^{19}$ Wawancara Dengan Bapak Khumaedi SH MKn
} Notaris/PPAT
Pekalongan. Dalam hal ini langkah yang harus dilakukan kreditur dalam melakukan peningkatan SKMHT menjadi APHT sampai dengan terbentuknya Hak Tanggungan adalah membuat surat permohonan kepada Notaris/PPAT untukmeningkatkan SKMHT tersebut menjadi APHT. Notaris/PPATdalam waktu 7 hari setelah penandatanganan pemberian hak tanggungan wajib mengirimkan APHT dan warkah lainnya kepada Kantor Pertanahan. Selanjutnya Kantor Pertanahan membuat buku tanah hak tanggungan dan mencatat dalam buku tanah hak atas tanah yang menjadi objek hak tanggungan dan menyalin catatan tersebut pada sertifikat hak atas tanah yang bersangkutan. Hak tanggungan lahir pada hari tanggal buku tanah hak tanggungan dibuatkan yang kemudian terbitnya Sertifikat Hak Tanggungan.

Dari pemaparan hasil wawancara penulis ditas dengan salah satu Notaris/PPAT, maka terdapat beberapa peran notaris dalam perjanjian Kredit Pemilikan Rumah (KPR) oleh Bank Tabungan Negara (BTN) Cabang Pekalongan. Peran dari Notaris/PPAT diantaranya membuat Akta Kuasa Menjual, Surat Keterangan Membebankan Hak Tanggungan (SKMHT), dan bilamana terjadinya debitur wanprestasi maka oleh Bank BTN Cabang Pekalongan mengajukan permohonan kepada Notaris/PPAT untuk meningkatkan Surat Keterangan Membebankan Hak Tanggungan (SKMHT) ke Akta Pemberian Hak Tanggungan (APHT), yang selanjutnya oleh Notaris/PPAT didaftarkan pada Kantor Pertanahan guna diterbitkannya Sertifikat Hak Tanggungan.

\section{SIMPULAN}

Dari pembahasan diatas dapat penulis simpulkan bahwa :

a. Penggunaan Surat Kuasa Membebankan Hak Tanggungan (SKMHT) dalam pemberian fasilitas Kredit Pemilikan Rumah (KPR) oleh Bank BTN Cabang Pekalongan dalam pelaksanaannya tidak diikuti dengan Akta Pemberian Hak Tanggungan (APHT), sehingga penggunaan SKMHT berlaku jangka waktunya sampai dengan berakhirnya perjanjian pokok, yakni perjanjian kredit tersebut. Dengan mengacu pada Peraturan Menteri Negara Agraria/Kepala Badan Pertanahan Nasional Nomor 4 Tahun 1996 tentang penetapan batas waktu penggunaan Surat Kuasa Membebankan Hak Tanggungan (SKMHT) untuk menjamin pelunasan kredit-kredit tertentu, yang dalam hal ini Kredit Pemilikan Rumah (KPR) bersubsidi oleh Bank BTN Cabang Pekalongan sebagai pemberi fasilitas. 
b. Upaya pihak bank apabila terjadi debitur wanprestasi terhadap fasilitas Kredit Pemilikan Rumah (KPR) oleh Bank Tabungan Negara (BTN) Cabang Pekalongan, terdapat beberapa upaya atau langkah-langkah yang dapat diambil baik dalam rangka penyelamatan aset kreditur maupun pemanfaatannya. Adapun upaya tersebut yakni dengan menggunakan akta kuasa menjual, peningkatan SKMHT ke APHT, upaya cessie, dan novasi.

c. Peran Notaris dalam perjanjian Kredit Pemilikan Rumah (KPR) oleh Bank Tabungan Negara (BTN) Cabang Pekalongan, diantaranya membuat Akta Kuasa Menjual, Surat Keterangan Membebankan Hak Tanggungan (SKMHT), dan bilamana terjadinya debitur wanprestasi maka oleh Bank BTN Cabang Pekalongan mengajukan permohonan kepada Notaris/PPAT untuk meningkatkan Surat Keterangan Membebankan Hak Tanggungan (SKMHT) ke Akta Pemberian Hak Tanggungan (APHT), yang selanjutnya oleh Notaris/PPAT didaftarkan pada Kantor Pertanahan guna diterbitkannya Sertifikat Hak Tanggungan.

\section{DAFTAR PUSTAKA}

Badrulzaman Mariam Darus, 2004, Kompilasi Hukum Jaminan, Mandar Maju, Bandung.

Habib Adjie, 2011, Hukum Notaris Indonesia, Tafsir Tematik Terhadap UU Nomor 30 Tahun 2004 Tentang Jabatan Notaris, Refika Aditama, Bandung.

Hadjon Phillipus M, 1987, Perlindungan Hukum bagi Rakyat Indonesia, PT Bina Ilmu, Surabaya.
Harsono Boedi, 1997, Hukum Agraria Indonesia / Sejarah Pembentukan Undang-Undang Pokok Agraria, Djambatan, Jakarta.

Hasbullah Fieda Husni, 2009, Hukum Kebendaan Perdata (Hak-hak Yang Memberi Jaminan) Jilid 2, IND HILL CO, Jakarta.

Hassanudin Rahman, 1995, Aspek-Aspek Hukum Pemberian Kredit Perbankan di Indonesia, PT. Citra Aditya Bakti, Bandung.

Muljadi Kartini, Gunawan Widjaja, 2005, Seri Hukum Harta Kekayaan: Hak Tanggungan, Kencana Prenada Media Group, Jakarta.

Sjahdeini Sutan Remy, 1999, Hak Tanggungan, Asas, Ketentuan-Ketentuan Pokok dan Masalah yang dihadapi oleh Perbankan; Suatu Kajian Mengenai Undang-Undang Hak Tanggungan, Alumni, Bandung.

Subekti R, 1985, Aneka Perjanjïan, Cetakan Ke VII, Alumni, Bandung.

Surat Keputusan Direksi Bank Indonesia No. 26/24/KEP/Dir. Tanggal 29 Mei 1993

Supramono Gatot, 2009, Perbankan dan Masalah Kredit : Suatu Tinjauan di Bidang Yuridis, PT. Rineka Cipta, Jakarta.

Tobing G.H.S. Lumban, 1992, Peraturan Jabatan Notaris, Erlangga, Jakarta.

Wawancara Dengan Legal Officer PT. Bank BTN Cabang Pekalongan, Pada Tanggal 26 Februari 2018.

Wawancara Dengan Bapak Khumaedi SH MKn Notaris/PPAT 